\title{
COVID-19, Sino-Nigeria Economic Relations and Consequences of Trade Deficits in Nigeria
}

\author{
Sunday Adiyoh Imanche ${ }^{1,2}\left(\mathbb{D}^{\circ}\right.$, Ze Tian $^{1^{*}}$, Tosin Yinka Akintunde ${ }^{\circledR}{ }^{\circ}$, Oluseyi Adewale Orelaja ${ }^{4}$, \\ Odette Tougem Tasinda ${ }^{1}$ \\ ${ }^{1}$ Business School of Hohai University, Nanjing, China \\ ${ }^{2}$ Department of Economics, Faculty of Humanities Management and Social Sciences, Federal University, Wukari, Nigeria \\ ${ }^{3}$ Department of Sociology, School of Public Administration, Hohai University, Nanjing, China \\ ${ }^{4}$ Moshood Abiola Polytechnic Ojeere, Abeokuta, Nigeria \\ Email: imanchesunny@gmail.com, *20031655@hhu.edu.cn, akintunde.ty@hhu.edu.cn, orhesheywal@yahoo.com, \\ teodetta@yahoo.com
}

How to cite this paper: Imanche, S. A., Tian, Z., Akintunde, T. Y., Orelaja, O. A., \& Tasinda, O. T. (2020). COVID-19, Sino-Nigeria Economic Relations and Consequences of Trade Deficits in Nigeria. Open Journal of Business and Management, 8, 2081-2092. https://doi.org/10.4236/ojbm.2020.85127

Received: August 4, 2020

Accepted: August 31, 2020

Published: September 3, 2020

Copyright $\odot 2020$ by author(s) and Scientific Research Publishing Inc. This work is licensed under the Creative Commons Attribution International License (CC BY 4.0).

http://creativecommons.org/licenses/by/4.0/

\section{(c) (i) Open Access}

\begin{abstract}
The COVID-19 Pandemic has disrupted the world economic and diplomatic relations between nations. The study investigates the effect of COVID-19 Pandemic on the political and economic ties between China and Nigeria. The consensus from recent literature shows that the Coronavirus pandemic has adversely affected economic and diplomatic relations between the two states. In particular, it has exposed Nigeria's over-reliance on importation from China. A mixed methodology was used to perform analysis of recent and past trade relations between China and Nigeria. We analyzed secondary data from UN COMTRADE on past trade relations with China. The outcome of the study shows that Nigeria trade relationship with China is booming. However, in the last decade, Nigeria has imported more foreign products from China than exportation. We also outline a necessary readjustment for trade balance to ensure an equal exporting opportunity to China to boost the Nigeria economy. It is crucial to stabilize relations between China and Nigeria as both countries need each other towards Sino-Nigeria Economic partnership.
\end{abstract}

\section{Keywords}

Trade Deficit, Nigerian Economy, COVID-19, Nigeria, China

\section{Introduction}

The COVID-19 Pandemic has hurt the global economy due to the closure of international borders and paucity in international trades. Consequently, it has re- 
sulted in economic and diplomatic tension among global actors. These tensions mainly revolved around supply and demands for medical and diagnostic equipment to safeguard the population and aid in the fight against COVID-19. Meanwhile, the economic impact of COVID-19 due to cessation in international trade is enormous. For instance, Nigeria, as a developing nation, is the heavy reliance on trade relationship with China and other developed countries with a diplomatic relationship.

As the world is on the brink of economic recession, the Pandemic has revealed the massive trade deficit between Nigeria and China and most importantly, the over-reliance of Nigeria on importation from China. It is no doubt that the trade agreement is targeted at fostering international cooperation between the two nations. However, it is vital for Nigeria to achieve trade balance and boost the economy to provide a viable coping mechanism for the impending economic recession. Currently, the small scale industries are receiving a massive blow from the COVID-19 outbreak. Without imports from China, many enterprises in Nigeria are at the risk of grounding to a halt. However, this may cause havoc on the economic growth of Nigeria within this period. Most production companies have resolved to a massive reduction of their workers due to the impact of COVID-19 (IBIS world, 2020). The lingering scourge of the COVID-19 Pandemic has crippled the small scales and large scale industries in Nigeria and consequentially crashed the Nigerian economy (Imanche et al., 2020).

Past economic relations between China and Nigeria have raised concerns about whether both country have a mutual benefit from the trade relationship (Umejei, 2015). These concerns also from a policy point perspective China's rising profile may alter the environment in which most African countries make trade policies (Ademola et al., 2016). Aside from the trade relationship, a significant number of Chinese private investors' own businesses have a high stake in private companies in Nigeria (Zafar, 2007). The domination of China in both international trade and private ownership of companies in Nigeria puts them in an advantageous position which may adversely affect the Nigerian economy if the balance of trade remains deficit. In reality, China's foreign direct investment in Africa is a small percentage of its international foreign direct investment (Ayodele \& Sotola, 2014). This reality puts Nigeria in a position to re-evaluate its foreign direct investment with Nigeria.

No doubt, China has contributed immensely to the economic growth and development of Nigeria by way of supply of manufactured goods. This study examines the effect of the COVID-19 Pandemic on the economic relations between China and Nigeria and the risk of financial collapse in Nigeria from the trade deficit. China is a vital manufacturing hub for many international business operations and holds a significant position in the global supply chain (Adekoya et al., 2020). China has assured mutually beneficial relationship with Nigeria (Adekoya, 2020), and proffered full support for numerous African countries through the assurance of solidarity and business cooperation during 
the COVID-19 Pandemic (Anyagafu, 2020).

With the assured support, there is an impending question on the ability of Nigeria to bolster production capacity to guarantee a balance of trade. At this time, Nigeria's industrial, agricultural, and construction sectors are reeling from the increased cost of business transaction and shortage in supply. The long-term cumulative effect of the impact of COVID-19 on a large scale and small industries in Nigeria is a cause for immediate concern and intervention. Similarly, given that China has resumed production and its international supply chain, Nigeria may be overly reliant on supplies from China. The amounts, however, do not indicate a negating effect until Nigeria is unable to balance its trades.

In effect, this study explored the past trade relationship between China and Nigeria, given the scepticism surrounding the current supply chain and the over-reliance of Nigeria on import from China (Walsh \& Kinkoh, 2020). The objective of this study is to:

1) Explore the past trade relationship between China and Nigeria.

2) Identify the current trade deficit between China and Nigeria.

3) To outlines the implication of the trade deficit on the Nigerian economy.

The subsequent pages addressed the past trade relationship between China and Nigeria. From the method section, we outlined the data source and data analysis approach for this study. We computed descriptive statistics for inferential purposes. The result section discusses the output of the frequency distribution of data collected and the graphical depiction of trends and findings. In the discussion, we outlined the impending danger of the current trade situation between Nigeria and China based on our analysis, consequences and necessary intervention. The first part of the discussion expatiated on the general effect of COVID-19 on supply chain and impact business dependent on these supplies. The second part outlined the implication of the Sino-Nigeria trade on the Nigerian economy. And lastly, we gave brief recommendations based on the current trends.

\section{Methodology}

\subsection{Data Source}

This research used secondary data from UN COMTRADE to analyze the trends of trade relations between China and Nigeria for over eleven (11) years. The adoption of this data was to give a clear explanation of past and current condition of import and export for both nations to support future adjustments and policies. UN COMTRADE is the pseudonym for the United Nations International Trade Statistics Database. Over 170 countries/areas supplied the United Nations Statistics Division (UNSD) with annual foreign trade statistics data detailed by commodities/service categories and cooperating countries. These data are transformed into the United Nations Statistics Division standard format with consistent coding and valuation using the processing system. 


\subsection{Data Analysis}

The data analysis focused mainly on descriptive analysis of the trade information between Nigeria and China. First, we presented the monetary equivalence of trade statistics (import and export) of Nigeria-China between 2009-2019. We employed the use of percentage distribution, graphical presentation of trends and bar chart for descriptive purpose only.

\section{Results}

\subsection{Nigeria-China Trade Statistics (2009-2019) Imports and Exports}

Table 1 shows the overall trade volumes that China has a total import above 223.0 percent imports to Nigeria as compares to table 23.0 percent of Nigeria total exports to China from 2009 to 2019. United Nations COMTRADE database on international trade indicates that Nigeria's share of the trade volume from 2009 to the end of December 2019 staggers at 23.0 percent. The value of Nigeria's total export for the eleven years was about $\$ 20.0$ billion as against the about $\$ 89.3$ billion the country frittered away on goods brought in from China as shown in Table 1 and Table 2. The total imports from china by Nigeria stood at USD $\$ 5.9$ billion at 18 percent out USD $\$ 34$ billions of total global imports to Nigeria in 2009. The trend was steady between 2012 to 2014 with the import percentage at 22 out of the total global imports to Nigeria. There was a $1.2 \%$ increase in 2015 and a 20\% steady import between 2016-2018 and recorded 25.4\% total importation in 2019.

Table 1. Nigeria-China trade statistics (2009-2019)-imports.

\begin{tabular}{cccc}
\hline Year & $\begin{array}{c}\text { Nigeria's total imports } \\
(\$ \text { million })\end{array}$ & $\begin{array}{c}\text { Imports from China } \\
(\$ \text { million })\end{array}$ & $\begin{array}{c}\text { \%Import from China in } \\
\text { total imports (\$ million) }\end{array}$ \\
\hline 2009 & $33,906,282$ & $5,999,532$ & 17.69445556 \\
2010 & $44,235,269$ & $7,324,399$ & 16.55782629 \\
2011 & $63,971,542$ & $9,447,757$ & 14.7686873 \\
2012 & $35,872,509$ & $7,715,361$ & 21.50772615 \\
2013 & $44,054,639$ & $9,561,454$ & 21.70362581 \\
2014 & $44,675,780$ & $9,794,923$ & 21.92445885 \\
2015 & $33,839,240$ & $7,876,937$ & 23.27752337 \\
2016 & $35,947,713$ & $7,071,114$ & 19.67055317 \\
2017 & $28,839,569$ & $5,393,208$ & 18.7007233 \\
2018 & $36,477,277$ & $7,080,498$ & 19.41070875 \\
2019 & $47,387,304$ & $12,064,658$ & 25.45968431 \\
Total & & & 223.0 \\
\hline
\end{tabular}

Source: ITC calculations based on UN COMTRADE statistics until January 2013 (Trading Economics, 2020). 
Table 2. Nigeria-China trade statistics (2009-2019)-exports.

\begin{tabular}{cccc}
\hline Year & $\begin{array}{c}\text { Nigeria's Total exports } \\
\text { (\$ million) }\end{array}$ & $\begin{array}{c}\text { Nigeria Export to China } \\
\text { (\$ million) }\end{array}$ & $\begin{array}{c}\text { \%export to China in } \\
\text { total Exports (\$ million) }\end{array}$ \\
\hline 2009 & $49,937,460$ & 716,921 & 1.43 \\
2010 & $86,567,913$ & $1,440,809$ & 2.0 \\
2011 & $125,641,031$ & $2,527,022$ & 2.01 \\
2012 & $143,151,183$ & $8,038,724$ & 6.0 \\
2013 & $89,450,809$ & $1,096,903$ & 1.22 \\
2014 & $98,773,957$ & $1,603,076$ & 2.0 \\
2015 & $48,465,647$ & 795,641 & 2.0 \\
2016 & $34,764,915$ & 497,940 & 1.43 \\
2017 & $41,010,138$ & 665,200 & 1.6 \\
2018 & $52,920,065$ & 881,827 & 2.0 \\
2019 & $53,624,701$ & $1,665,243$ & 3.1 \\
Total & & & 23.0 \\
\hline
\end{tabular}

Source: ITC calculations based on UN COMTRADE statistics until January 2013 (Trading Economics, 2020).

In regards to manufactures and related enterprises, the supply chain disruption is already affecting the raw materials needed for production. While some Nigerian manufactures had built an inventory across time, they are increasingly becoming apprehensive about access to necessary raw materials required to sustain the enterprises. Table 1 and Table 2 showed the volume of trade between China and Nigeria between 2009 and 2019 when trade between the two countries was at its peak (please refer to Figure 1).

Trade data of 2019 when the agreement of currency swap between Nigeria and China came into full effect was expected to show fairer trade relations. Sadly, Nigeria's import from China leapt by 1.6 percent, as shown in Figure 1, climbing from about $\$ 7.8$ billion recorded in 2018 to about $\$ 12.6$ billion. The value of export inched further but by less than 3.1 percent, as shown in Table 2 and Figure 2. The improved performance saw the country's low export to China move from US\$1.04 Billion in 2018 to US\$1.55 Billion in 2019 (Mbamalu et al., 2020). However, trade disparities seem not to affect the trade relationship between $\mathrm{Ni}$ geria and China, and this is due to the manufacturing capacity of China in the global business environment. The China trade relationship meets the Nigerian aims to become one of the world's top economies (Egbula \& Zheng, 2011).

\subsection{Balance of Trade between China and Nigeria (April 2019-January 2020)}

As shown in Figure 3, the trade balance in Nigeria swung to a USD $\$ 424.7$ million gap in March of 2020 from a USD\$ 1.2 billion surplus a year earlier. Exports plunged 33.5 percent to USD\$2.5 billion, the lowest value since March of 2017 


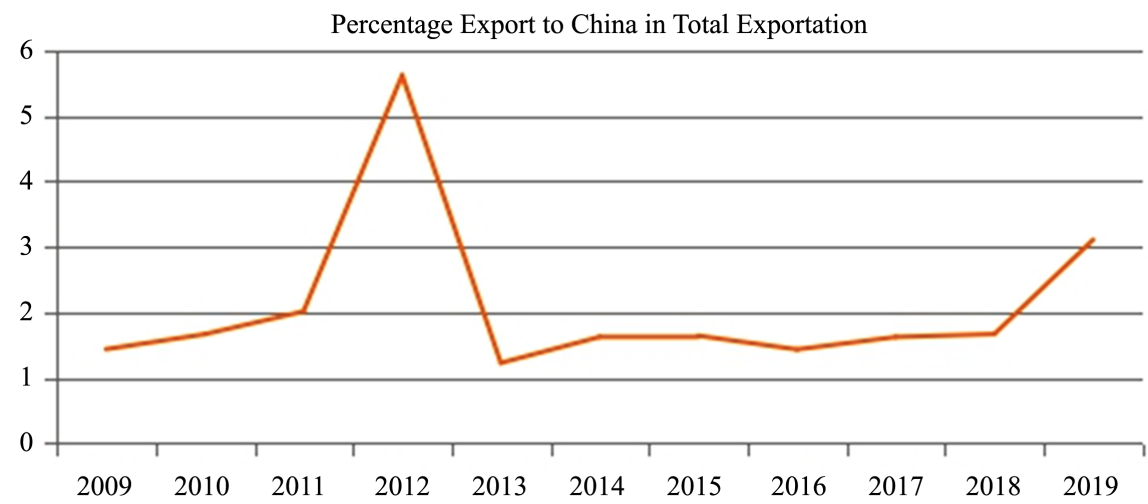

Figure 1. Percentage export to china in total exportation on bilateral between (2009-2019). Source: Authors calculation base on UN COMTRADE data 2009-2019.

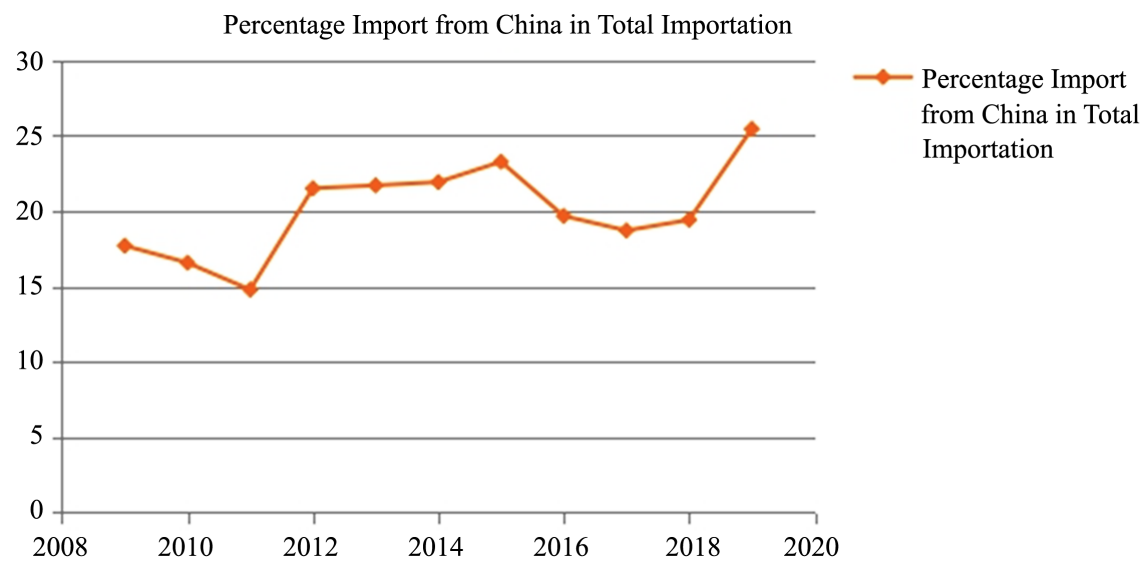

Figure 2. Percentage export to china in total exportation on bilateral between (2009-2019). Source: authors calculation base on UN COMTRADE data 2009-2019.

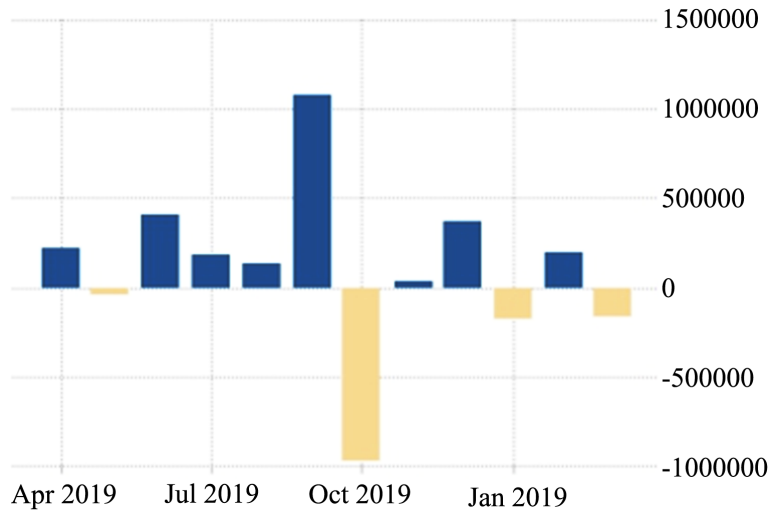

Figure 3. Nigeria's balance of trade (June 2019-January 2020). Source: (Trading Economics, 2020).

while imports increased 12.6 percent to USD $\$ 2.9$ billion. In the first quarter of the year, Nigerians trading account recorded a USD\$ 361 Million gap compared to a USD\$ 2.2 billion surplus a year earlier. Exports went down 10 percent year-on-year as sales of mineral products which account for 85 percent of total 
shipments, dropped 12 percent, mainly due to crude oil (-12.8 percent). Imports rose 14 percent, most purchases of boilers, machinery and appliances (11 percent); mineral products (172.5 percent), namely crude oil (180 percent) and vehicles, aircraft and vessels (27.5 percent). China, India, the Netherlands and Spain were the main trading partners in Q1 (Trading Economics, 2020).

\section{Discussions}

\subsection{The Implication of COVID-19 on Industries Dependent on Chinese Importation in Nigeria}

The coronavirus pandemic and the subsequent lockdown are an indication of how the consequences of such risks can go beyond control. The impact of COVID-19 Pandemic has affected the global supply chain in the world, and China as a significant supplier of raw material for manufacturing firms in Nigeria has reduced its production capacity. Many service providers and manufacturers in Nigeria are already feeling a steep shortage of intermediate inputs and raw materials (Tadesse, 2020). This occurrence has consequences for employment creation and retention, the suitability of the supply of products to Nigeria's market, and capacity utilization. Over $\$ 100$ million of goods that belong to computer and phone vendors in Nigeria are lying in China (Adekoya et al., 2020). Since critical original equipment manufacturers (OEM) in China have seized productions, the only thing traders in Nigeria can do take caution with their depleting stocks (Sun, 2020). The outbreak has proved to be a real pain to Nigeria's supply link with China.

To Nigerians and other Africans countries, it is seen as an obstacle to supply of manufactured goods from China as China is the primary source of imports for most African countries (Isaac et al., 2020).

Suppliers in the Nigerian market are at high risk of being impacted by the Pandemic, which may eventually force businesses across the globe to remain at a standstill as they take time to find new suppliers. Fewer suppliers in the market may contribute to non-consistency in trade matters. Goods may be delayed, which may affect relationships between countries. For example, the case of Apple by (Helft, 2011), experienced massive demand surges and strain on its supply chains in ordinary times and causing long week delays in meeting orders. The suspension affects companies awaiting services or products, and they end up losing their relationship with their customers. Fewer suppliers in Nigeria may be at risk of financial collapse due to the COVID-19 Pandemic. The suppliers may be forced to close down and fail to function as expected to cause a big blow to their clients. Fewer suppliers place the companies at huge risks such as lack of manufacturing facilities and backup inventory as they tend to focus on functioning with less redundancy (Baker et al., 2020). Fewer suppliers might affect companies negatively if they are faced with possibly inflated logistic lead times for emergency products. Most importantly, they will lead to a poor balance of trade. 


\subsection{The Trade Balance between China-Nigeria and the Long-Run Implication on the Nigerian Economy}

This study attempted to explore the importance of balancing trade between China and Nigeria. Over the last decade, there has been obvious dependence on importation from China. Analytically we explored the Nigeria-China trade statistics between 2009 to 2019 to present our finds. In retrospect, Nigeria has failed to diversify the economy, and the drawback is obvious during the COVID-19 Pandemic. The lack of diversification means that Nigeria's economy is susceptible to the economic and financial shocks caused by the Pandemic (Adekoya et al., 2020). The lack of diversification, the risk of the economic recession is threatening the Nigerian economy, which is further compounded by the COVID-19 Pandemic. Subsequently, the analysis of the trade relationship between China and Nigeria could potentially impact the Nigerian economy in the following way.

Firstly, the past trade relationship highlights the differentials in the cross benefit between both countries. While Nigeria imported more from China, Nigeria export less. There are questionable indices as to why there is this imbalance. Nigeria, over the years, became more of an importing country than an exporting country. Although the government has in the past enacted importation policies in an attempt to reduce over-reliance on the importation, some have argued that it may increase poverty in the country (Treichel et al., 2012). The manufacturing industry of Nigerian has been crippled in the last two decades; hence it explains the reliance on importation from other countries.

Secondly, the trends in the importation and exportation between China and Nigeria show that the is economy booming, and there was an equivalent increase in exportation to China between 2011 to 2013. This increment was largely due to an increase in the manufacturing of goods in high demand from China. The subsequent fall requires further analysis to establish a sharp fall in exportation that happened in 2013. In contrast, over the last ten years, Nigeria has consistently imported from China and 2019, and it suffices that the reliance on importation will persist if an immediate adjustment is not implemented.

Lastly, the monetary return from China falls short of what Nigeria remit to China. This shortfall implies that rather than increase the GDP, Nigeria has turned to a spending nation and have failed to bolster important sectors of the economy. However, since there is a trade agreement between both countries, Nigeria needs to harness the opportunity presented by the trade agreement to begin to encourage the production of products in high demand by China.

\section{Recommendations and Call for Intervention}

For environments that have increasingly turned to be global, more parties are involved, and less information is made available in various stages within the manufacturing process. As a result, it becomes tough to recognize, prioritize, quantify and diminish risks for an effective decision-making process (Barrios \& 
Hochberg, 2020). The expansion of companies internationally requires decisions to be made irrespective of whether all the necessary data is obtainable. Regrettably, if there is no implementation of collaboration systems and appropriate communication, the absence of information is linked to risk intensification. Globalization brings about the probability that companies will be open to and obstructed by adverse happenings, such as economic instability and volatility, supply interferences, natural disasters, among many more (Savitz, 2012). Complexity in supply chains intensifies in various ways. The production process has turned out to be exceedingly more complicated compared to a simple get-together line. Nigerian manufacturers at present are required to accomplish a variety of product lines that need assembling of parts from diverse suppliers. Confusion finds its way when the parts need sub-assembly by different suppliers. Additionally, manufacturers are required to work on logistics in discovering where products should be in meeting demand globally. The broad geographic segments where products sole continues to rise with an increase in rules which was put by the various suppliers home countries and the merchants from the importing countries due to the outbreak of the COVID-19 Pandemic. Globalization contributes to increased competition, which is perceived as a huge challenge and risk to international manufacturers. The manufacturers find it hard to tell whether the low-cost bidder requires multiple design modifications in their global businesses and if they can offer the relevant working intelligence and traceability.

In the reduction of risks, Nigerian manufacturers need to take a broad and more holistic standpoint in handling multifaceted supply chains. The implementation of technologies that can enhance visibility within the supply chain should be considered. Manufacturers should be in a position to collaborate and communicate with suppliers efficiently. In this case, reliable financial and experienced world-class suppliers should be sought. Visibility tools should be used in tracking international shipments and act when necessary. For example, the Total Risk Analysis (TRA) tool incorporated by IBM in 2011 during the Japanese tremor and tsunami, responded correctly within a short time. The tool collects a mass of data from various dimensions. According to (Dittmann, 2014), IBM was able to detect all its possible supplier glitches, quickly drew together the details and established backup plans. Leading organizations make use of the supply-chain event management innovations in sending alarms to crucial personnel when there is a need to carry out a particular action within the international supply chain in communicating possible delays. As risks turn out to be more strategic, they regularly encompass high levels of indecision that may influence capital investments. As such, organizations need to get access to a more comprehensive framework, and the aptitude to examine a variety of scenarios and a particular model for costing and risk options. Nigeria needs to adopt a global platform for handling the project range to have better visibility in disabling regional barriers and, at the same time, developing appropriate contingency plans. 
It would be advantageous for Nigeria to have suppliers from several nations to stop its overreliance on China for imports and the simple fact that products need to get to the shelves as soon as the manufacturing bit is done. A successful business needs timely delivery of merchandise for an increase in sales and profits. The move would, in turn, lead to higher customer acceptance. Having suppliers in different countries would make for a fully integrated supply chain, which is the hallmark of successful corporations. The various threats encountered by the global supply chain include natural disasters, epidemics, terrorist attacks, geopolitical threats and fluctuations of currency. Risks like the COVID-19 Pandemic are unknown and can be mitigated through various ways like adaptability, which needs all the elements of the supply chain to share a similar inclination and place effort towards the same goals hence becoming better placed to react towards a particular crisis. Another way of managing the unknown is to increase the velocity in detecting and responding, thus helping a company to bypass unanticipated supply issues like the COVID-19 Pandemic. The other sources of risks that are known and somehow controllable can be managed through developing speculative strategies and hedge strategies. Hedge strategies, for instance, involve gains in another counterweigh a company designing the logistics network in a manner that any lose in one section of the chain.

\section{Conclusion}

The COVID-19 Pandemic has had effects on the political and economic relations between China and Nigeria. Undoubtedly, the outbreak of the novel coronavirus has significantly altered the relationship between countries, and this can be seen in the ties between China and Nigeria. The Pandemic has exposed the overreliance of Nigeria on Chinese goods to sustain its manufacturing sector. The decline of the global supply chain has adversely affected Nigerian traders as they are unable to access products from China, hence affecting the economic relationship of the two countries. However, the Pandemic has illuminated the need for Nigeria to realign its trade networks and for China to stem out harassment. The ultimate aim is to ensure an improved Sino-Nigeria economic relationship after the Pandemic

\section{Research Limitation}

The critical limitation of this study was that inferences were made solely from descriptive statistics and might not entirely give a futuristic forecast of the trade relationship between China and Nigeria.

\section{Ethical Approval}

No ethical approval was required for this study. The study explored public data.

\section{Funding}

No funding was received for this publication. 


\section{Conflicts of Interest}

The authors declare no conflicts of interest regarding the publication of this paper.

\section{References}

Adekoya, F. (2020). Coronavirus Affecting Nigeria \& China Relation-Belt \& Road News. https://www.beltandroad.news/2020/04/30/coronavirus-affecting-nigeria-and-china-rel ation

Adekoya, F., Adeyemi, A., Sulaimon, S., \& Alade, B. (2020). How Coronavirus Outbreak Threatens Nigeria's Economy. The Guardian Nigeria News Nigeria and World News. https:/guardian.ng/news/how-coronavirus-outbreak-threatens-nigerias-economy

Ademola, O. T., Bankole, A.-S., \& Adewuyi, A. O. (2016). China-Africa Trade Relations: Insights from AERC Scoping Studies. In S. Henson, \& O. F. Yap (Eds.), The Power of the Chinese Dragon. Palgrave Readers in Economics (pp. 69-97). London: Palgrave Macmillan. https://doi.org/10.1007/978-1-137-57449-7 4

Anyagafu, V. (2020). Nigeria: China to Cancel Debt of Relevant African Countries. AllAfrica.Com. https://allafrica.com/stories/202006220728.html

Ayodele, T., \& Sotola, O. (2014). China in Africa: An Evaluation of Chinese Investment (p. 20).

Baker, S. R., Bloom, N., Davis, S. J., \& Terry, S. J. (2020). COVID-Induced Economic Uncertainty (Working Paper No. 26983; Working Paper Series). Cambridge, MA: National Bureau of Economic Research. https://doi.org/10.3386/w26983

Barrios, J. M., \& Hochberg, Y. (2020). Risk Perception through the Lens of Politics in the Time of the COVID-19 Pandemic (Working Paper No. 27008; Working Paper Series). Cambridge, MA: National Bureau of Economic Research. https://doi.org/10.3386/w27008

Dittmann, J. P. (2014). Managing Risk in the Global Supply Chain-Supply Chain Management Review.

https://www.scmr.com/article/managing risk in the global supply chain

Helft, M. (2011). Some Worry That Apple's Magic Is Stuck in Japan. The New York Times. https://www.nytimes.com/2011/03/23/technology/23apple.html? r=0

IBIS World, I. I. (2020). Coronavirus Update: Industry Fast Facts. IBISWorld Industry Insider.

https://www.ibisworld.com/industry-insider/coronavirus-insights/coronavirus-updateindustry-fast-facts

Imanche, S. A., Ze, T., Tougem, T. O., \& Dalibi, S. G. (2020). Effect of COVID-19 Pandemic on Small and Medium Scale Businesses in Nigeria.

Isaac, O., Akyuz, M., \& Victor, I. (2020). Nigeria-China Trade: The Coronaviruses (COVID-19 COVID 19) Challenges and Benefits.

Savitz, E. (2012). Managing the Risks of a Globalized Supply Chain. https://www.forbes.com/sites/ciocentral/2012/10/04/managing-the-risks-of-a-globalize d-supply-chain/\#59f869d81d03

Sun, Y. (2020). COVID-19, Africans' Hardships in China, and the Future of Africa-China Relations. Brookings.

https://www.brookings.edu/blog/africa-in-focus/2020/04/17/covid-19-africans-hardshi ps-in-china-and-the-future-of-africa-china-relations 
Tadesse, L. (2020). Testing the Relationship: China's "Corona Diplomacy" in Africa. ECDPM.

https://ecdpm.org/talking-points/testing-relationship-china-corona-diplomacy-africa

Trading Economics (2020). China Imports. https://tradingeconomics.com/china/imports

Treichel, V., Hoppe, M., Cadot, O., \& Gourdon, J. (2012). Import Bans in Nigeria Increase Poverty.

Umejei, E. (2015). China's Engagement with Nigeria: Opportunity or Opportunist? African East-Asian Affairs, 3-4, 54-78. https://doi.org/10.7552/0-3-4-165

Walsh, B., \& Kinkoh, H. (2020). COVID-19 and the Conundrum of China-Africa Relations. London: Feature from King's College.

https://www.kcl.ac.uk/covid-19-and-the-conundrum-of-china-africa-relations

Zafar, A. (2007). The Growing Relationship between China and Sub-Saharan Africa: Macroeconomic, Trade, Investment, and Aid Links. The World Bank Research Observer, 22, 103-130. https://doi.org/10.1093/wbro/lkm001 